\title{
REASONING FOR IMPROVING NORMS OF ELECTROMAGNETIC SAFETY OF EMPLOYEES OF ELECTRICAL ENGINEERING ENTERPRISES
}

\section{Rieznik, S. Sukach}

Kremenchuk Mykhailo Ostrohradskyi National University

vul. Pershotravneva, 20, Kremenchuk, 39600, Ukraine. E-mail: 2411dimareznik@gmail.com

T. Kozlovs'ka

Kremenchuk flight college of Kharkiv National University of Internal Affairs

vul. Peremogy, 17/6, Kremenchuk, 39605, Ukraine. E-mail: kozlovskaya5819@gmail.com

L. Levchenko

National Technical University of Ukraine «Igor Sikorsky Kyiv Polytechnic Institute»

prosp. Peremohy, 37, Kyiv, Ukraine, 03056 E-mail: larlevch@ukr.net

Purpose. Analysis of domestic and foreign experience regarding the determination of the boundaries of the magnetic component of electromagnetic fields of industrial frequency from various electrical equipment and their impact on the health of workers involved in energy-intensive industries is the aim of the article. Methodology. During the performance of their duties, employees for a long time are in close proximity to the electrical equipment, the influence of the magnetic component manifests itself in changing the work of individual cells, and in changing the work of organs, systems or the human body as a whole. Results. Under the influence of the magnetic field induction, in cells, several response mechanisms are triggered, namely ion-resonance, hydration, generation of active oxygen species, and the creation of modified forms of proteins. Depending on the genetic heredity and the state of human health, the listed processes lead to disorders in the cardiovascular, immune, endocrine, nervous, sexual and APUD systems of the human body. In this case, the influence of the magnetic component of the electromagnetic fields has a carcinogenic character and accumulates in the human body, which in the future leads to an increase in the risk detection of various types of cancer at 2-4.6 times. Practical value. Based on the results of the influence of magnetic fields of industrial frequency on human health, an analysis of internationally permissible rules for the propagation of magnetic field induction has been carried out, which showed that only a few countries of the world have now directed their efforts to protect their citizens. This is noticeable in the established permissible limit of $0.2 \mu \mathrm{T}$. In most countries of the world to adopt such rules that do not allow to improve the working conditions. References 23, tables 2, figures 4.

Key words: low frequency electromagnetic fields, electrical equipment, human health, regulatory framework.

\section{ОБГРУНТУВАННЯ ВДОСКОНАЛЕННЯ НОРМАТИВІВ 3 ЕЛЕКТРОМАГНІТНОЇ БЕЗПЕКИ ПРАЦІВНИКІВ ПІДПРИЕМСТВ ЕЛЕКТРОТЕХНІЧНОЇ ГАЛУЗІ}

\section{Д. В. Резнік, С. В. Сукач}

Кременчуцький національний університет імені Михайла Остроградського

вул. Першотравнева, 20, м. Кременчук, 39600, Україна. E-mail: 2411dimareznik@ gmail.com

Т. Ф. Козловська

Кременчуцький льотний коледж Харківського національного університету внутрішніх справ

вул. Перемоги, 17/6, м. Кременчук, 39605, Україна. E-mail: kozlovskaya5819@gmail.com

\section{Л. О. Левченко}

Національний технічний університет України «Київський політехнічний інститут імені Ігоря Сікорського» просп. Перемоги, 37, м. Київ, Україна, 03056 E-mail: larlevch@ukr.net

Стаття спрямована на аналіз вітчизняного та закордонного досвіду стосовно визначення меж поширення магнітної складової електромагнітних полів промислової частоти від різноманітного електротехнічного обладнання та дослідження їх впливу на стан здоров'я працівників, які задіяні на енергоємних виробництвах. Під час виконання своїх службових обов'язків працівники тривалий час, протягом зміни, знаходяться в безпосередній близькості від електротехнічного обладнання, вплив магнітної складової проявляється як у зміні роботи окремих клітин, так і у зміні роботи органів, систем чи організму людини в цілому. Під дією індукції магнітного поля в клітинах запускається декілька механізмів відгуку, а саме: іон-резонансний, гідратний, генерація активних форм Оксигену, створення модифікованих форм білків. Залежно від генетичної спадковості та стану здоров'я людини перелічені процеси призводять до розладів у роботі серцево-судинної, імунної, ендокринної, нервової, статевої та APUD систем людського тіла. При цьому вплив магнітної складової електромагнітних полів має канцерогенний характер і властивість накопичуватися у організмі людини, що в подальшому призводить до збільшення ризику в 2-4,6 рази виявлення різних видів онкологічних захворювань. Базуючись на отриманих результатах впливу магнітних полів промислової частоти на стан здоров'я людини проведено аналіз міжнародних гранично допустимих норм поширення індукції магнітного поля, який показав, що на даний момент тільки декілька країн світу спрямували свої зусилля на захист своїх громадян. Це проявляється у встановлені допустимого обмеження на рівні 0,2 мкТл. У більшості країн світу прийняті такі норми, що не дозволяють покращити умови праці.

Ключові слова: низькочастотні електромагнітні поля, електротехнічне обладнання, здоров'я людини, нормативно-правова база. 
PROBLEM STATEMENT. Sustainable development of electrical engineering and computer technology allows creating a variety of devices, which, on the one hand, simplify the technological process, and, on the other hand, deteriorate the electromagnetic environment at the production. For energy-intensive industries, a large number of various electrotechnical equipment (EE) is located at the sites of the working environment, forming a complex picture of the spatial distribution of electromagnetic fields (EMF). At the same time, employees, in accordance with the conditions of production, are constantly forced to stay in close proximity to the EE. Thus, workers are subjected to overinfluence of magnetic fields of the industrial frequency of $50 \mathrm{~Hz}$, which leads to a negative impact on their health. At the same time, it should be noticed that in modern realities a person is practically constantly under the influence of low-frequency EMF. About the increase of EMF levels in homes can be evidenced by the fact that over the past 10-15 years the current rated fuses and circuit breakers at the input of the power network in apartments increased from 5-6 to 20-25 A. This means an increase in power consumption in the 10-25 times and, consequently, an increase in the EMF levels in apartments by 5-6 times. Thus, the human body has little time to restore.

Today, the results of research on the influence of EMF on human health in this area are somewhat ambiguous and sometimes quite contradictory. Therefore, the World Health Organization (WHO) has extended the ALAR principle to EMF (as low as reasonably - as low as reasonably achievable). This principle is an integral part of the latest version of the Pan-European Directive on Worker Electromagnetic Safety [1], which requires the employer to create the conditions for maximizing the risk of negative changes in the health of workers under the influence of electromagnetic factors.

In this regard the major task become an assessment of changes in the tissues, organs, and systems of the body during the influence of electromagnetic fields from production equipment, in the immediate proximity of which people are working during the day.

Currently, it is considered that the level of electromagnetic pollution has not yet become globally dangerous. However, much more often there is an excess of normalized maximum permissible levels of EMF take place. But changes in the biological environment indicate otherwise: in the human body protective reactions are formed more prolonged in time, because for EMF is a characteristic effect of potentiation with the expansion of harmful and dangerous effects.

Taking into account the abovesaid the purpose of the work is to conduct research on the influence of EMF of industrial electrical equipment on the physiological conditions of a person in order to develop an appropriate complex of labor protection means and further improvement of the legal and regulatory framework on this issue in Ukraine.
EXPERIMENTAL PART AND RESULTS OBTAINED. Modern production is based on the use of innovative technologies, which involves a variety of powerful EE as a source of EMF.

Completion of the program for the production of finished products requires the interaction of man with electrotechnical equipment in the workplace. Worker in the workplace for a long time (duration of shift 8-12 hours) is subject to physical (electromagnetic factors, physical properties of the air environment, mechanical factors: noise, vibration, acceleration), chemical (natural gas composition of air, harmful impurities in the air), biological (microorganisms, pathogens, viruses), socio-psychological and aesthetic factors.

Then, depending on the use of EE, workplaces can be divided into three categories [2]:

- I category - safe electrical equipment is used EMF emission is in the normal state. Work with such equipment does not require any instructions and the use of additional protective equipment;

- II category - divided into two subcategories: IIa - work with electrical equipment, which requires certain instructions, namely observance of a safe distance; IIb - work with electrical equipment with the use of technical means, namely, reducing the intensity of the source of emission, installation of protective screens and warning signs;

- III category - dangerous equipment characterized by significant EMF emissions. The electrical equipment of this category requires the use of a wide range of technical means and methods for the reorganization of production.

In industrial conditions, the main sources of EMF are distribution substations, transformers, power cables, electric machines (EM), energy converters, etc. Distribution substations and power transformers, assigned from the workplace to a safe distance and additionally fenced. Electric machines, power converters, and power cables are located directly on the workplace or on a small distance from it. The power cables are covered with an earthed envelope, which greatly reduces the EMF emission.

By the 70's of the twentieth century. It was considered that the EMF of industrial frequency in comparison with high-frequency EMF is safe and does not affect human health. Over time, in the advanced countries of the world, the impact on the human health of a magnetic field (MF) of industrial frequency has been recorded among workers at factories and inhabitants of residential areas. Subsequently, studies were carried out at the systemic level, which allowed to highlight the causes and effects of the MF of industrial frequency. The result was the formation of magnetobiology, a science that studies biological effects as a result of weak low-frequency MF and does not cause tissue heating. It also began to record cases of cancer.

There are three groups of carcinogenic factors by the level of harm to human health [3]. EMF of industrial 
frequency belongs to the third group, namely "Possibly carcinogenic to humans".

At current stage of the development of magnetology, there are several explanations of the primary mechanisms of biological action of weak MF, which lead to a change in the structure of cells, tissues, organs or the organism as a whole. MP is characterized by a perforating factor $[4,5]$, which simultaneously acts on all cells and tissues of an organism, therefore, at different levels of organization of living matter, synchronous multilevel effects are implemented that systematically lead to nonspecific reactions.

Theories of MF influence on human health are based on consideration of a number of primary mechanisms, namely:

- ion resonance mechanism, which is characterized by the fact that the MF operates on biologically important ions, that is $\mathrm{Ca}^{2+}, \mathrm{Mg}^{2+}, \mathrm{K}^{+}, \mathrm{Na}^{+}$and etc. Thus, for example ions $\mathrm{Ca}^{2+}$. It was established that under the influence of $\mathrm{MF}$ ions of $\mathrm{Ca}^{2+}$ lose the hydrated shell and move into a viscous state, which leads to an inactive functional state of the cell. The description of this process in terms of classical physics is not correct enough, and in more detail the magnetic-biological effects are explained by the phenomenon of quantum interference [4];

- hydrated mechanism. Human body at 70-80\% consists of water, and MF affects the physical and chemical properties of water, water solutions and colloidal systems. The primary acceptor of weak EMF is the water phase, a fractal quasicrystal structure that is actually in a metastable state and is constantly changing as a result of the spontaneous flow of free radical processes in it and spontaneous rearrangements of the spatial organization of hydrogen bonds [6]. Thus, the change in the properties of the water phase leads to changes in the dynamics of the intramolecular segments of protein molecules, and, consequently, to the change in the structural and functional properties of proteins;

- mechanism of active form oxygen generation - an indirect factor through the structural rearrangement of water molecules. This is due to the fact that during the restructuring of water molecules in the interaction of clusters there is a rupture of covalent bonds in the water molecule and the generation of atoms of Hydrogen and radicals $\mathrm{OH}^{*}$ [7]. Consequently, increasing the amount of free radicals in water leads to an increase in the number of DNA breaks [8];

- a mechanism for the creation of modified forms of proteins starts with a change in the hydrophobic properties in the biomacromolecules when the nonpolar molecules are bonded with biopolymers and membranes, the change in the properties of the double layer and the production of free radicals, which in the future leads to an increase in the influence of the destructive factor in case of interaction with the MF [9].

The given mechanisms of influence of MF operate simultaneously in the middle of a cell, and to distinguish from them the most influential is very difficult, as much depends on the functional features of the cell and the initial physical state. In addition, the frequency- amplitude and exposure characteristics of the MF should be taken into account. At the same time, some scientists have isolated the cells of the human body, which are the most sensitive to the influence of MF, that is cells belonging to the group of APUD-system [10].

The APUD-system is a connecting element between the nervous, endocrine, cardiovascular, sexual and immune systems. Physiological role - regulation of almost all biological processes at all levels - from subcellular to systemic [11]. APUD-system consists of about 60 types of cells found in the central nervous system, endocrine glands, the thymus, lymph nodes, gastrointestinal tract, lungs, kidneys and urinary tract, paraganglia, placenta and connective tissue. In these cells, under the influence of MF, a cascade of reactions is initiated, which leads to changes in the water-salt, energy, trophic and gas balance in tissues. As a result, the load on the cardiovascular, immune, endocrine and nervous systems increases. In the future, this leads to disorders of human health.

Therefore, when planning labor protection measures to protect a person from the EMF influence, it is necessary to determine the effects of electromagnetic fields on changes in organs, tissues, individual organs and systems with constant finding in the circle of their mutual influence.

In the course of the research it was found that the most revealing are changes in electrical conductivity, dielectric permeability, and the determination of the angle tangent of changes in dielectric permeability of human fat and bone tissue, which is described by the corresponding mathematical dependencies with the reliability of approximation $\mathrm{R} 2=0,87-0,95$ [12]:

- dielectric permeability

$$
y= \pm a x^{3}+b x^{2} \pm c x+k
$$$$
\text { - dielectric losse }
$$$$
y=a x^{4} \pm b x^{3}+c x^{2}-d x+k
$$

- conductivity

$$
y= \pm a \operatorname{Ln}(x) \pm b .
$$

The results indicate that the largest changes in adipose tissue are in the range of EMF frequencies from 1 to $100 \mathrm{kHz}$. In this range of tissue, structural changes occur most at the molecular level, as the spatial orientation of the molecules of fats, the components of molecules, may change - the change in lipophilic properties of lipophilic ones. This means that the adipose tissue loses its protective properties with respect to EMF influence, it loses the ability to shield electromagnetic emission. Reliable interconnection is established between dielectric permittivity and the tangent of the angle of dielectric losses (Pearson correlation coefficient 0,9804 ).

From our point of view, the greatest losses are observed in the range of $5 \mathrm{~Hz}-100 \mathrm{kHz}$ (the most common frequency of operating industrial equipment) associated with the change in the biochemical properties of atoms and molecules that form bone tissue. At the same time, the optical properties of the molecules also change, and, consequently, the stability of cell membranes to the influence of electromagnetic waves. 
Also, under the influence of electromagnetic fields, the chemical and biologically active D (-) - isomers of amino acids, proteins, peptides on inactive $\mathrm{D}(+), \mathrm{L}(-)$ isomers are replaced, that is, in the general case racemates are formed - biochemical structures that are not able to react on the action of EMF, which leads to loss of protective properties of biological tissues, organs and systems from the effects of EMF. In this regard, it is necessary to analyze in more detail the causes of loss of protective properties.

In our opinion, this is due to the loss of the protective barrier of muscle tissues, the violation of the functions of the head and bone marrow (Fig. 1-3).

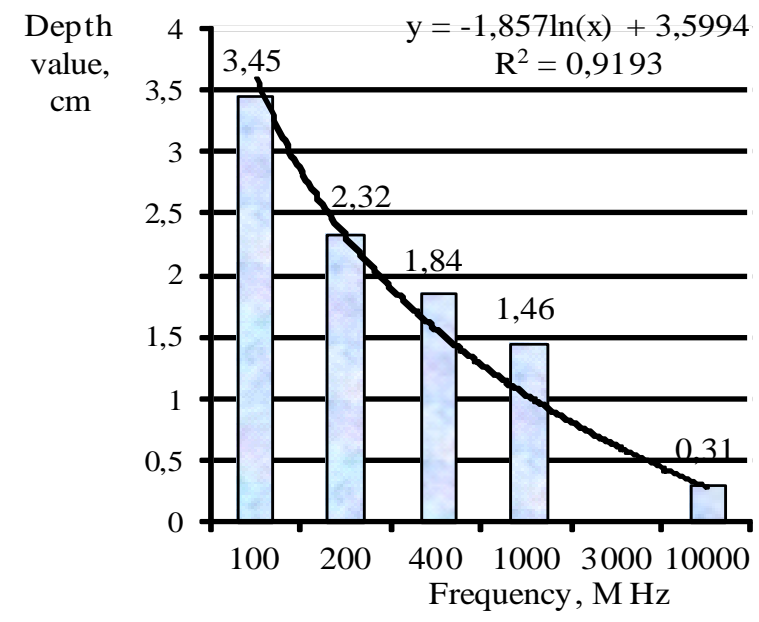

Figure 1 - Depth of penetration of EMF in muscle tissue

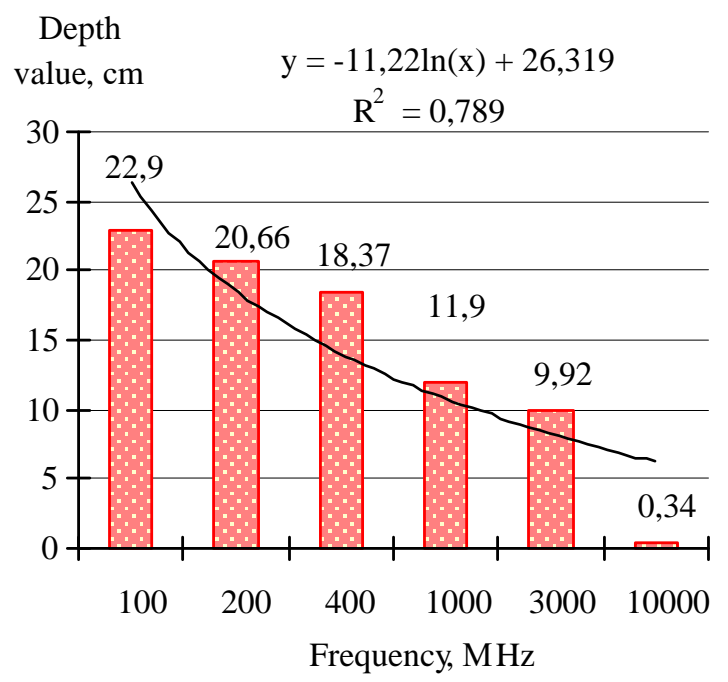

Figure 2 - Depth of penetration of EMF in the bone marrow

It should be emphasized that the interaction of molecules of biological objects with an electromagnetic field can not be considered separately - as interaction with electric and magnetic fields. From our point of view, the influence of the electromagnetic field is based on the orientation of atoms and molecules in the direction of the field and against it, that is, in accordance with the laws of quantum mechanics, two levels of electromagnetic energy of atoms and molecules are possible: the spin of the nuclei of atoms or molecules as a set of atoms parallel to the intensity of the electromagnetic field or antiparallel to her. From a biochemical point of view, in this case one can speak of the parallel and antiparallel orientation of the electron spins of atoms and molecules of biological tissues and organs exposed to the electromagnetic field. Then the energy difference between two spin states can be described by the equation:

$$
\Delta E=\frac{\gamma B_{o} h}{2 \pi},
$$

where $\gamma-$ a hydromagnetic ratio characterizing the nucleus of each individual atom or atoms that form a separate molecule, $s^{-1} T^{-1} ; B_{o}-$ magnetic induction of the active electromagnetic field, $T ; h$ - Planck's constant.

$\Delta E$, which corresponds to two spin states of individual atoms or a set of atoms of individual molecules, is a function of an active electromagnetic field and a hydromagnetic relation:

$$
\Delta E=f\left(B_{o}, \gamma\right) \text {. }
$$

Depth

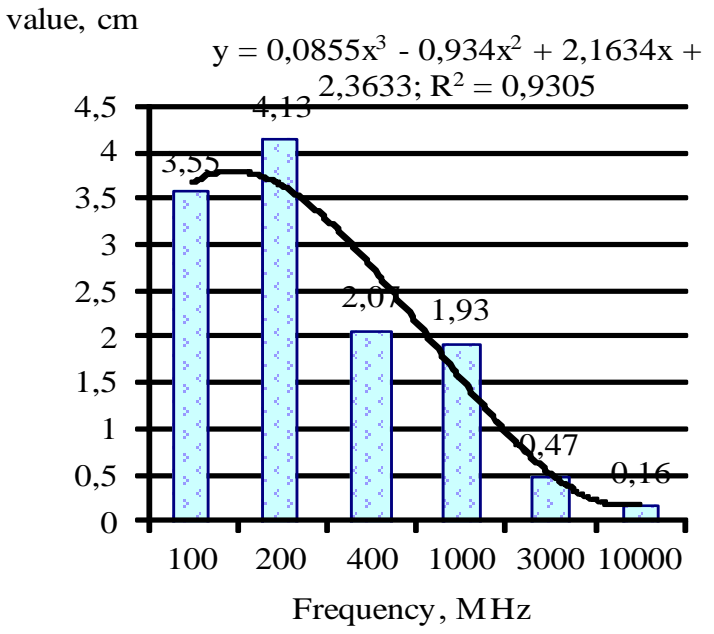

Figure 3 - Depth of penetration of EMF in the brain

Then, the hydromagnetic ratio, which is defined as the ratio of the magnetic and mechanical moments of atoms or molecules, is a characteristic of the interaction of atoms or molecules with the electromagnetic field and, ultimately, will determine the biochemical changes in the tissues and organs of the biological object - in our case, the changes in workers health under the influence of electromagnetic fields of electrical equipment in industrial premises. Consequently, the total self-negative effect on tissues, organs and living organisms is invested in the probabilistic normal distribution of harmful effects on the health of workers depending on the frequency of EMF (Fig. 4), and in general exceeds the permitted level of 10-6 over the entire frequency range. 


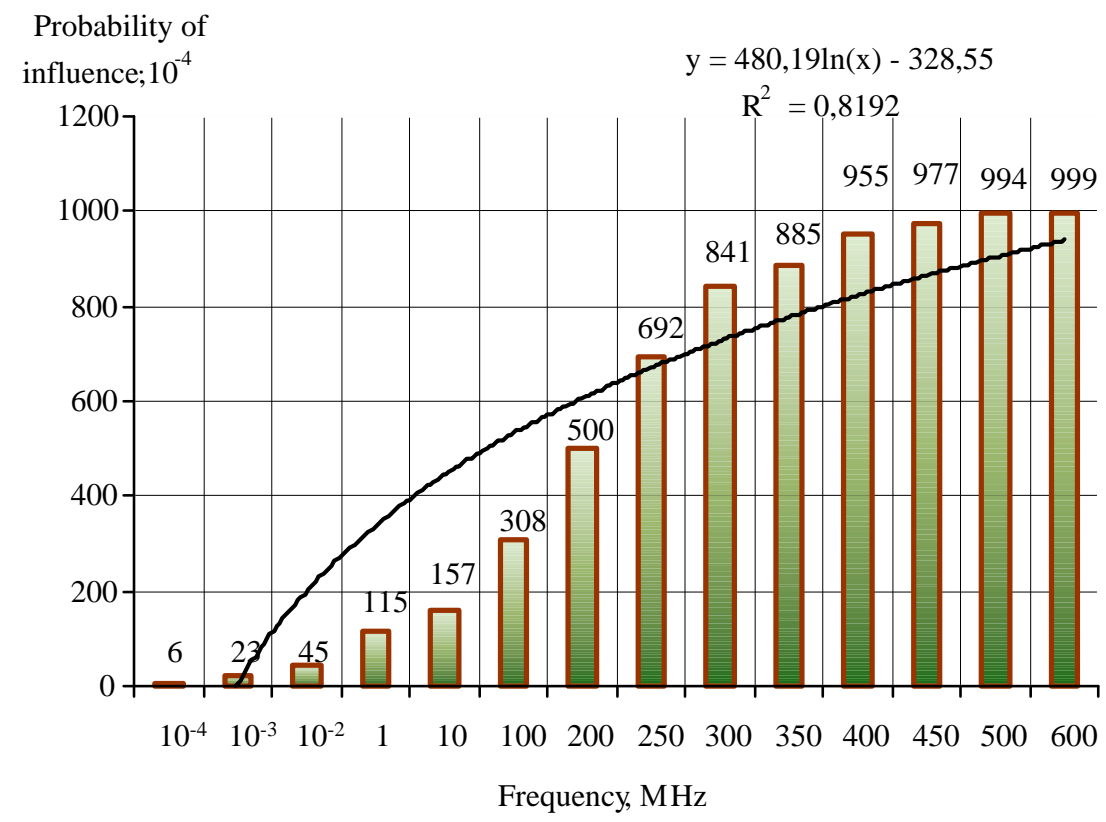

Figure 4 - Total probabilistic-normal distribution of the influence of EMF power on the frequency of health workers

At normal temperatures characteristic of biological objects, chemical bonds experience fluctuations under the action of an electromagnetic field with a certain frequency of waves. In any case, the energy absorption of this field occurs, which leads to an increase in the amplitude of the oscillations of chemical bonds of atoms and molecules in tissues and organs. In this case, we can talk about the so-called valence fluctuations of carbon-carbon, carbon-hydrogen, carbon-oxygen, carbon-nitrogen and etc. The frequency of valence oscillations of chemical bonds is described by the equation (Hooke's law):

$$
v=\frac{1}{2 \pi c} \sqrt{\frac{k}{\mu}},
$$

where $v$ - frequency of valence oscillations; $\mu$ - The given mass of communication is defined as $\frac{m_{1} m_{2}}{m_{1}+m_{2}}$ ( $m_{1}, m_{2}-$ the mass of atoms that formed the chemical bond); $k$-constant, which determines the energy bond strength, that is, the relation of the energy of the formation of the connection to the energy of its rupture; $c$ - speed of light.

Consequently, if the frequency of the waves of the electromagnetic field is equal to or greater than the frequency of the valence fluctuations of chemical bonds, then the atoms, tissue molecules, and, accordingly,

the fabric as a whole, feel the influence of the electromagnetic field, i.e., their own deformation and rotational vibrations of the ions, electrons lead to the breakdown of chemical compounds The molecules of biological tissues, organs and systems of humans, in connection with which they lose their screenprotective properties from the influence of electromagnetic fields.

In connection with the foregoing, the identification of the hazards of the influence of factors of physical pollution is a kind of diagnosis of the presence of harmful environmental factors, in particular, and the process of establishing cause-and-effect relationships between their effects and changes in the state of human health. Thus, in the Tabl. 1 shows relative risks (RR), confidence intervals (CI), and statistics on the detection of cancer among the working population of the United States, Canada, United Kingdom, France, Sweden, Denmark, Norway, Italy, China, Thailand and Australia according to $[3,13]$.

By analyzing occupational diseases, IARC specialists have established a number of occupations whose workers are most exposed by the influence of EMF of industrial frequency, among them [8]:

electronic engineers;

electrical engineers; electricians;

electrical installers;

staff serving the telephone lines, radio stations, power stations;

electric welders;

repair technicians of electrical equipment;

cinema mechanics.

Thus, during studies in the above-mentioned countries, among the workers from the above specialties, it was found that the number of premature deaths associated with different types of cancer tumors is increased: for men 1.4 times and for women -1.3 [8].

Based on the foregoing, it can be noted that the MF of extremely low and industrial frequencies are influenced onto human health, namely, the impairment of the immune, cardiovascular, endocrine, nervous, sexual and respiratory systems, the gastrointestinal tract, changes in blood and DNA [14]. With local MF influence, itching, pallor, cynosiness, puffiness, fatigability, etc. (Tabl. 1). 
Table 1 - Influence of the magnetic field of industrial frequency on human health

\begin{tabular}{|c|c|c|}
\hline Level of MF, $\mu \mathrm{T}$ & $\begin{array}{l}\text { The source of the } \\
\text { MF }\end{array}$ & Influence on a person (or biological object) \\
\hline \multirow[t]{3}{*}{$>0.2$} & \multirow[t]{2}{*}{ Energy industry } & The risk of myeloid leukemia in adults is 2.3 times higher \\
\hline & & The risk of malignant skin melanoma in adults increases by 2.6 times \\
\hline & Railway transport & The risk of developing brain cancer in adults increases by 2.6 times \\
\hline $0.2-10$ & Transmission lines & $\begin{array}{l}\text { Increasing the risk of cancer. Side amyotrophic sclerosis. } \\
\text { CI } 1.05-3.55 \% ; \text { RR } 1.93 \%\end{array}$ \\
\hline \multirow[t]{2}{*}{$>0.3$} & Energy industry & The risk of myeloid leukemia among adults increases 2.7 times \\
\hline & $\begin{array}{l}\text { Energy industry, } \\
\text { communication } \\
\text { system }\end{array}$ & The risk of breast cancer in adults increases by 2 times \\
\hline $0.3-0.4$ & Transmission lines & $\begin{array}{l}\text { The risk of leukemia in children is } 2 \text { times higher. } \\
\text { CI } 1.06-1.61 \% \text {; RR } 1.31 \%\end{array}$ \\
\hline$>0.4$ & Energy industry & $\begin{array}{l}\text { The risk of myeloid leukemia in adults is } 4.6 \text { times higher. } \\
\text { CI } 0.77-3.46 \% \text {; RR } 1.63 \%\end{array}$ \\
\hline$>0.41$ & Energy industry & The risk of testicular cancer in men is increased in 2.1 times \\
\hline $0.5-50$ & & $\begin{array}{l}\text { Characterized by the growth of transformed cells in the liver. Increased } \\
\text { activity of glycolytic reactions and increased lactic acid production in } \\
\text { different tissues (fatigue) }\end{array}$ \\
\hline $0.8-1$ & $\begin{array}{l}\text { Transmission lines } \\
220-380 \kappa \mathrm{V}\end{array}$ & $\begin{array}{l}\text { The risk of Alzheimer's disease and aging weakness of mind increases. } \\
\text { CI } 1.21-3.33 \% \text {; RR } 2.0 \%\end{array}$ \\
\hline 1 & & $\begin{array}{l}\text { Shortening of the phase of slow sleep. Reduced attention. Reduced } \\
\text { activity of human brain cells. Tendency to stress. } \\
\text { CI } 0.93-3.43 \% \text {; RR } 1.78 \%\end{array}$ \\
\hline 1.4 & & $\begin{array}{l}\text { Genetic changes: the effect on the synthesis of peptides that perform the } \\
\text { functions of biological sensors }\end{array}$ \\
\hline $4.28-15.45$ & Energy industry & The risk of lung cancer in adults increases by 1.5 times \\
\hline 20 & & Small changes in the heart function, pulse reduction at $3-5$ beats/min. \\
\hline $0.01-30$ & & Risk of breast cancer rises \\
\hline
\end{tabular}

In recent years, the attention of domestic labor protection specialists has been focused on electromagnetic safety (EMS) [3, 15]. This is due to the fact that a number of international commissions investigated the impact of EMF on human health $[3,16]$. The commission's conclusions indicated the carcinogenicity of the MF of industrial frequencies, which may lead to negative consequences in the work of the cardiovascular, immune, endocrine, sexual and immune systems during prolonged staying in the zone of activity of the fields. On this basis, attention should be paid to the regulatory framework. There are currently two standards of EMS in Ukraine [17, 18]. The norms have significant differences, namely the application of different maximum permissible emission levels of EMF and the determination of the influence of several sources of EMF.

In addition to the above, there is another particular disadvantage in using these two standards. The drawback is to recommend the use of screens to protect workers from the effects of EMF, but it does not specify how one or another screen is selected depending on the type, source and power of emission. It does not take into account the material from which the screens are made and how they can distort the picture of the EMF. Inappropriate selection of material for the manufacture of a protective screen and imperfect screen design can increase the risk of the negative impact of EMF on human health [19].

It should be noted, another problem, namely, the inconsistency of the standards of electromagnetic security in Ukraine with the electromagnetic compatibility of technical means. Thus, thanks to the Order of the Ministry of Economic Development of Ukraine dated 29.14. №1483 from 01.01.2016, the European regulations on electromagnetic compatibility $[20,21]$ and others entered into force in Ukraine. Thanks to the documents introduced, the level of electromagnetic safety of the workers increases due to the normalization of the amplitudes of the harmonics of the electric current of the industrial frequency and increases the stability of the equipment operation. The negative moment of the introduction of these norms is their rigidity, especially, the incompatibility of the standardized working conditions of people with the normative conditions of the work of technical means. Therefore, national standards on electromagnetic safety and electromagnetic compatibility requirements should be harmonized and linked to the European directive [22]. The said directive is based on the conclusions of the international commission [23].

The national values of the maximum permissible levels of EMF in the production environment significantly exceed the maximum permissible levels in accordance with the international norms of ICNIRP.

For comparison in Tabl. 2 shown the maximum permissible levels of EMF values in different countries of the world. 
Table 2 - Permissible levels of EMF values in different countries of the world

\begin{tabular}{|l|c|c|c|}
\hline \multirow{2}{*}{ Country } & \multirow{2}{*}{ Regulatory document } & \multicolumn{2}{c|}{ Magnetic induction level, $\mu$ T } \\
\cline { 3 - 4 } & For industrial premises & For public premises \\
\hline \multirow{2}{*}{ EU Recommendations } & ICNIRP 1998 & 500 & 100 \\
\cline { 2 - 4 } & ICNIRP 2010 & 1000 & 200 \\
\cline { 2 - 4 } & EU 2013 & $0.4-3000$ & 360 \\
\hline USA & ICES 2002 & 2710 & $904(15)$ \\
\hline Ukraine & ДCHiП 3.3.6.096-2002 & 1750 & 100 \\
\hline Australia & ARPANSA 2007 & 500 & 0.4 \\
\hline Latvia & EU 2013 & 0.4 & 424 \\
\hline Germany & EU 2013 Law 04 & 1358 & 100 \\
\hline United Kingdom, & EU 2013 & 1000 & 0.2 \\
Netherlands & & 0.4 & $10 ; 3$ \\
\hline Italy & N.104,6/5/1992. 2003 & 100 & 100 \\
\hline Russian Federation & СанПиH 2.2.4.3359-16 & 1000 & \\
\hline Sweden, Switzerland & & 0.25 & \\
\hline
\end{tabular}

From the given data in the Tabl. 2 it is shown that in almost all countries of the world there is a significant excess of indicators of magnetic induction.

CONCLUSIONS. As a result, the analysis of the regulatory framework allows noticing the discrepancy between national normative documents and with international standards.

The obtained results of the research showed the need to protect people from the effects of magnetic fields of industrial frequency, which is associated with an increased risk of various types of cancer detection by 2 4.6 times. Therefore, it is necessary to reduce the maximum permissible level of magnetic field induction up to $0.2 \mu \mathrm{T}$

During labor protection measures planning to protect workers from the influence of electromagnetic fields it is necessary to take into account their influence on changes in organs, tissues, separate systems as the results of constant finding of a person in the zone of influence of electromagnetic fields, in which they lose protective properties due to decrease of relative permittivity and increase of penetration depth of corresponding frequency EMF.

\section{REFERENCES}

1. Directive 2013/35/EU of the European Parliament and of the Council of 26 June 2013 on the minimum health and safety requirements regarding the exposure of workers to the risks arising from physical agents (electromagnetic fields).

2. Bolte, J. F. B., \& Pruppers, M. J. M. (2006). Electro-magnetic fields in the working environment. Ministry of Social Affairs and Employment (SZW) report.

3. (2002). IARC working group Part 1: static and extremely low-frequency (ELF) electric and magnetic fields. IARC Monograph on the Evaluation of Carcinogenic Risks to Humans, 80 (1), 395.

4. Martynjuk, V. S., Cejsler, Ju. V., \& Temurjanc N. A. (2012). Interferencija mehanizmov vlijanija slabyh jelektromagnitnyh polej krajne nizkih chastot na organizm cheloveka i zhivotnyh.
Geofizicheskie processy i biosfera, 11 (2), 16-39. [in Russian]

5. Bingi, V. N., \& Savin, A. V. (2003). Fizicheskie problemy dejstvija slabyh magnitnyh polej na biologicheskie sistemy. Uspehi fizicheskih nauk, 173 (3), 265-300. [in Russian]

6. Belova, N. A., Epmakov, A. M., \& Znobishheva, A. V. (2010). Vlijanie krajne slabyh peremennyh magnitnyh polej na regeneraciju planarij $\mathrm{i}$ gravitacionnuju reakciju rastenij. Biofizika, 55 (4), 704-709. [in Russian]

7. Voeikov, V. L. (2006). Fundamental role of water in bioenergetics. Biophotonic and coherent systems in biology. New York; N.Y. USA: Springer, 89-104.

8. Testa, A. et al. (2004). Evaluation of genotoxic effect of low level $50 \mathrm{~Hz}$ magnetic fields on human blood cells using different cytogenetic assays. Bioelectromagnetics, 25 (8), 613-619.

9. Kudrjashov, L. V., Lobkaeva, E. P., Aleksandrov, R. S., \& Devjatkova, N. S. (2006). Ispolzovanie metodiki rascheta magnitnogo polja pri issledovanii radioprotektornogo jeffekta dejstvija impulsnogo vihrevogo magnitnogo polja. Slabye $i$ sverhslabye polja i izluchenija $v$ biologii i medicine: tez. dokl. 4-go Mezhdunarodnogo kongressa, 03-07 July 2006. Sankt-Peterburg, 115. [in Russian]

10. Martynjuk, V. S., \& Abu Hada, R. Sh. H. (2003). Reakcija tuchnyh kletok na dejstvie morfina i magnitnogo polja $\mathrm{v}$ uslovijah in vitro. Uchenye zapiski Tavrich. nac. un-ta im. V. I. Vernadskogo. Ser. Biologija, himija, 16 (55), 28-34[in Russian]

11. Lukjanchikov, V. S. (2005). APUD-teorija v klinicheskom aspekte. Rossijskij medicinskij zhurnal, 13 (26), 1808-1811. [in Russian]

12. Kozlovs'ka, T. F., Sukach, S. V., \& Levchenko, L. O. (2016). Kryterii vplyvu elektromagnitnyh poliv na organizm ljudyny pry planuvanni praceohoronnyh zahodiv. Visnyk Nacionalnogo tehnichnogo universytetu Ukrainy «Kyivskyj politehnichnyj instytut». Serija «Girnyctvo», 31, 87-96. [in Ukrainian] 
13.Kheifets, L. et al. (2010). Pooled analysis of recent studies on magnetic fields and childhood leukaemia. British Journal of Cancer, 103 (7), $1128-1135$.

14. Stozharov, A. N. (2016). Rukovodstvo po bezopasnosti zdorov'ya $i$ blagopoluchiya na rabote (elektromagnitnye polya) [A guide to the safety healh and welfare at work (electromagnetic fields)]. [in Russian]

15. Khalmuradov, B. D., Levchenko, L. O., Gliva, V. A., \& Perelot, T. M. (2015). Problemi uzgodzhenosti normativnoï bazi $\mathrm{z}$ elektromagnitnoi sumisnosti ta elektromagnitnoi bezpeki. Nauka i tekhnika Povitryanikh Sil Zbroynikh Sil Ukraini, 4, 103-106. [in Ukrainian]

16.Jinsheng, Lai et al. (2016). Effects of 100- $\mu \mathrm{T}$ extremely low frequency electromagnetic fields exposure on hematograms and blood chemistry in rats. Journal of Radiation Research, 57, (1), 16-24.

17.(1996). Derzhavni sanitarni normi $i$ pravila zakhistu naselennya vid vplivu elektromagnitnikh viprominyuvan: DSN 239-96. [State sanitary norms and rules of protection of the population from the influence of electromagnetic radiation: DSN 239-96]. Kiev: MOZ Ukraini. [in Ukrainian]

18. (2003). Derzhavni sanitarni normi i pravila pri roboti $z$ dzherelami elektromagnitnikh poliv D San Pin 3.3.6.096-2002. [State sanitary norms and rules when working with sources of electromagnetic fields $D$ San Pin 3.3.6.096-2002]. Kiev: MOZ Ukraini. [in Ukrainian]

19. Panova, O. V. Ekranuvannya elektromagnitnikh poliv ta zabezpechennya elektromagnitnoï sumisnosti elektronnogo obladnannya. Upravlinnya rozvitkom skladnikh sistem, 22, 207-213. [in Ukrainian]

20.International Standard: EN 61439-1: 2011 Lowvoltages witch gearandcontrol gearassemblies. General rules.

21. EN 61439-5: 2011 Low-voltage switchgear and controlgear assemblies. Assemblies for power distribution in public networks.

22. European Parlament and Council, Directive 2013/35/EU of 26 June 2013 on the minimum health and safety requirements regarding the exposure of workers to the risks arising from physical agents (electromagnetic fields).

23. (1998). ICNIRP Guidelines for limiting exposure to time-varying electric, magnetic and electromagnetic fields (up to $300 \mathrm{GHz}$ ). International Commission on Non-Ionizing Radiation Protection. Health Physics, 74, 494-522.

\section{ОБОСНОВАНИЕ УСОВЕРШЕНСТВОВАНИЯ НОРМАТИВОВ ПО ЭЛЕКТРОМАГНИТНОЙ БЕЗОПАСНОСТИ РАБОТНИКОВ ПРЕДПРИЯТИЙ ЭЛЕКТРОТЕХНИЧЕСКОЙ ОТРАСЛИ}

\section{Д. В. Резник, С. В. Сукач}

Кременчугский национальный университет имени Михаила Остроградского

ул. Первомайская, 20, г. Кременчуг, 39600, Украина. E-mail: 2411dimareznik@ gmail.com

\section{Т. Ф. Козловская}

Кременчугский летный колледж Харковского национального университета внутренних дел

ул. Победы, 17/6, г. Кременчуг, 39605, Украина. E-mail: kozlovskaya5819@ gmail.com

\section{Л. А. Левченко}

Национальный технический университет Украины

«Киевский политехнический институт имени Игоря Сикорского»

просп. Победы, 37, г. Киев, 03056, Украина. E-mail: larlevch@ukr.net

Работа посвящена анализу отечественного и зарубежного опыта определения границ распространения магнитной составляющей электромагнитных полей промышленной частоты от различного электротехнического оборудования и исследованию влияния на состояние здоровья работающих, задействованных на энергоемких производствах. При исполнении своих служебных обязанностей работники продолжительное время, на протяжении рабочей смены находятся в непосредственной близости от электротехнического оборудования, влияние магнитной составляющей которого проявляется в изменении работы как отдельных клеток организма, так и в изменении работы органов, систем или всего организма в целом. Под действием индукции магнитного поля в клетках запускается несколько механизмов, в частности: ион-резонансный, гидратный, генерация активных форм кислорода, создание модифицированных форм белков. В зависимости от генетической предрасположенности и состояния здоровья человека указанные выше процессы приводят к нарушению работы сердечно-сосудистой, иммунной, эндокринной, нервной, репродуктивной и APUD систем человеческого тела. При этом влияние магнитной составляющей электромагнитного поля имеет канцерогенный характер и свойство накапливаться в организме человека, что в дальнейшем приводит к увеличению риска выявления различных онкологических заболеваний в 2-4,6 раза. На основе полученных результатов исследований проведен анализ международных предельно допустимых норм распространения индукции магнитного поля. Показано, что на данный момент только несколько государств направили свои усилия на защиту граждан от действия электромагнитных полей и магнитной его составляющей. Это проявляется в установлении допустимого ограничения на уровне 0,2 мкТл. В большинстве мировых государств приняты нормы, не позволяющие улучшить условия труда на промышленных предприятиях.

Ключевые слова: низкочастотные электромагнитные поля, электротехническое оборудование, здоровье человека, нормативно-правовая база. 